\title{
Possible Protective Effect of Melatonin on Cisplatin-Induced Testicular Toxicity in Adult Albino Rats. A Histological and Immunohistochemical Study
}

\section{Original Article}

\author{
Soheir Assaad Filobbos ${ }^{1}$, Noha Mohamed Afifi Amin', Mira Farouk Youssef \\ Yacoub $^{1}$, Khaled Ragab Abd El-Hakim ${ }^{2}$
}

Histology Department, Faculty of Medicine, ${ }^{1}$ Cairo University, ${ }^{2}$ Misr University for Science and Technology, Egypt

\begin{abstract}
Introduction: Chemotherapy may result in temporary or permanent gonadal toxicity in male patients. Loss of fertility potential can be devastating to patients, especially, during the child-bearing period.

Aim of Work: The present study was planned to investigate the possible protective effect of melatonin, in a rat model of cisplatin-induced testicular toxicity.

Materials and Methods: Forty five adult male albino rats (180-200 grams each) were divided into four groups; Group I Control $(n=15)$ received $0.9 \%$ sodium chloride and/or distilled water as a vehicle. Group II ( $n=10)$ were injected intraperitoneally (I.P.) with a single dose $7 \mathrm{mg} / \mathrm{kg}$ of cisplatin\& were sacrificed after 10 days. Group III (n=10) received melatonin daily orally at a dose of $8 \mathrm{mg} / \mathrm{kg} /$ day for 10 days. Group IV $(\mathrm{n}=10)$; oral melatonin administration started 5 days before the single I.P. injection of cisplatin, followed by continuation of melatonin for further 10 days. Testicular sections were subjected to H\&E, immunohistochemical staining for anti-inducible nitric oxide synthase (iNOS) and anti-androgen receptor (AR).

Results: The study proved the protective effect of melatonin against testicular toxicity, when administered prior to and concomitant with cisplatin therapy; confirming the anti-oxidant potential of melatonin.

Conclusion: Our findings provide experimental evidence ensuring the protective effect of melatonin, when administered prior to, and concomitant with the chemotherapeutic agent cisplatin. Meanwhile, melatonin administered alone seemed to induce injury to the testis.
\end{abstract}

Received: 27 December 2019, Accepted: 02 February 2020

Key Words: AR, cisplatin, iNOS, melatonin, rat testis.

Corresponding Author: Khaled Ragab Abd El-Hakim, M.D., Histology Department, Faculty of Medicine, Misr University for Science and Technology, Egypt, Tel.: +20 1000616346, E-mail: khaled_rag@yahoo.com

ISSN: $1110-0559$, Vol. 43, No.3

\section{INTRODUCTION}

Chemotherapy is an important modality in cancer treatment. One of the most commonly used chemotherapeutic agents is the cisplatin that revealed a powerful effect during management of many cancer types that affect the human being such as head, neck, lung, colorectal, hematologic, ovarian and testicular cancers ${ }^{[1]}$.

Cisplatin has been introduced as main components of most of the standard clinical protocols in treatment of different types of cancers, so many laboratory studies were conducted to illustrate the molecular mechanisms of the anti-tumor effect of this efficient platinum-derived alkylating agent. As reported from these studies, Cisplatin mediate its effect mainly during the "S Phase" of the cell cycle; binding to and causing cross linking of DNA that initiates cell death through apoptosis, necrosis or both. Cisplatin has also been suggested to generate free radicals by interaction with $\mathrm{DNA}^{[2]}$.

One of the most serious complications caused by cisplatin, which was reported in different studies, is the testicular toxicity that is caused by the high mitotic activity of spermatogenic cells ${ }^{[3]}$. The harmful effects of Cisplatin on the male fertility include azospermia, abnormalities in sperm morphology, impairment of spermatogenesis and reduction of testosterone levels in rats ${ }^{[4]}$.

\section{AIM OF THE WORK}

This study was conducted to assess the possible protective effect of the anti-oxidant drug Melatonin, in a rat model of Cisplatin-induced testicular toxicity, as well as to elucidate the underlying protective mechanisms, as detected by biochemical, histological and immunohistochemical methods.

\section{MATERIALS AND METHODS}

\section{A-Materials}

Drugs

a) Cisplatin: manufactured by Mylan, France, andwas purchased from Pfizer chemical company (USA) in the form of vial $10 \mathrm{mg} / 10 \mathrm{ml}$. The drug was given IP at a dose of $7 \mathrm{mg} / \mathrm{kg}$ single dose $\mathrm{e}^{[5]}$. 
b) Melatonin (MLT): tablet form of melatonin (each tablet contains $3 \mathrm{mg}$ of melatonin) was used in this study. It was manufactured by Puritan Pride, INC (USA) and purchased from Sigma Chemical Company (St Louis, Missouri, USA). Tablets were crushed, dissolved in distilled water and were given orally at a dose of $8 \mathrm{mg} / \mathrm{kg} /$ day for 10 days by the use of a gastric tube ${ }^{[6]}$. Each tablet was dissolved in water.

\section{Animals}

The study was performed at the Animal House of Kasr-Al Aini School of Medicine, according to the ethical guidelines for the Care and Use of Laboratory Animals. Total number of forty five adult male albino rats ( 12 weeks old) was used in this study, with weight range between 180 and $200(185 \pm 1.25)$ grams. They were housed in hygienic stainless steel cages and kept in clean well-ventilated room. They were fed standard chow diet and allowed free access to water

\section{Experimental design}

\section{Animals were divided into the following groups}

Group I (Control Group): (15 rats)

Subgroup 1a:- received $0.9 \%$ sodium chloride (the vehicle of cisplatin) daily for 10 days.

Subgroup 1b:- received distilled water (the solvent for melatonin). daily for 10 days.

Subgroup 1c:- received distilled water for 5 days, then distilled water and $0.9 \%$ sodium chloride for another 10 days.

Control rate received vehicle by the same route of drug administration and were sacrificed with the corresponding experimental groups.

Group II (Cisplatin-Treated Group):(10 rats) were injected I.P. with a single dose of cisplatin $7 \mathrm{mg} / \mathrm{kg}$. Rats were sacrificed 10 days after cisplatin injection.

Group III (Melatonin-Treated Group): (10 rats) received melatonin daily orally at a dose of $8 \mathrm{mg} / \mathrm{kg} / \mathrm{day}$ at 5:00 pm for 10 days.

Group IV (Melatonin Pre-treated / Co-Treated Group): (10 rats). Oral melatonin administration started 5 days before the single I.P. injection of cisplatin, followed by continuation of MLT therapy for further 10 days. Rats were sacrificed 10 days after cisplatin injection.

\section{B-Methods}

\section{I- Serological Investigations}

Tail vein blood samples were collected at day zero and at the end of each experimental period, for measuring hormonal profile of serum Testosterone by ELISA (Biosource, TM, ELISA Kits, USA) ${ }^{[7]}$ performed at the Biochemistry Department, Faculty of Medicine, Cairo University.

\section{II-Sample Collection \& Processing}

Phenobarbital at a dose of $60 \mathrm{mg} / \mathrm{kg}$ was used to anaesthetize rats by injection through I.P. route ${ }^{[8]}$. Rats were sacrificed and both testes from each rat were dissected out

For biochemical analysis, right testes were minced, homogenized and centrifuged ${ }^{[9]}$. The supernatant was used to measure "markers of oxidative stress":

i. Malondialdehyde (MDA): this aldehyde is used as a biomarker to measure the level of oxidative stress in cells ${ }^{[10]}$. Lipid peroxidation was assessed by measuring MDA in testicular tissues using the thiobarbituric acid method ${ }^{[11]}$

ii. Superoxide: It is deployed by the immune system to kill invading microorganisms ${ }^{[12]}$. Estimation of superoxides was done using colorimetric method $^{[13]}$.

Left testes were processed for light microscopic studies. Left testes were fixed in Bouin's solution for 24 hours at room temperature, and after that ascending grades of alcohol $(70 \%, 95 \%, 100 \%)$ were used to dehydrate the specimens, cleared in xylene then embedded into paraffin wax (Histology Department, Faculty of Medicine, Cairo University). Paraffin blocks were cut at $5 \mu \mathrm{m}$ thickness, using Leica rotator microtome (Germany).

For evaluation of testicular changes after cisplatin therapy and the effect of MLT consumption, with exposure to the following stains:

A. Hematoxylin and Eosin stain ${ }^{[14]}$.

B. Immunohistochemical staining using the avidinbiotin peroxidase complex technique ${ }^{[15]}$ for detection of:

1. Inducible nitric oxide synthase (iNOS): group of enzymes used to produce nitric oxide (NO) from L-arginine ${ }^{[16]}$.

2. Androgen Receptor (AR): Androgen receptor is a member of the superfamily of ligand responsive transcription regulators ${ }^{[17]}$.

\section{III) Quantitative Morphometric Study}

In every specimen, the following parameters were evaluated by a Leica Qwin 500 LTD image analysis computer system, (Cambridge, UK):

1. Height of seminiferous epithelium (measured in microns in H\&E-stained sections), extending from the basement membrane of the seminiferous tubule towards the lumen.

2. Mean optical density of inducible nitric oxide synthase (iNOS) immunoreactivity (measured in iNOS-immunostained sections).

3. Mean area $\%$ of androgen receptor (AR) immunoreactivity (measured in ARimmunostained sections). 


\section{IV) Statistical Analysis}

Data were tabulated and statistically analyzed to evaluate the difference between the groups under study as regards the various parameters. Correlations were evaluated in between the essential studied parameters. The statistical analysis included; the arithmetic mean, standard deviation, analysis of variance (ANOVA). The probability $(\mathrm{P})$ value obtained from statistical tables was directly supplied by the computer using SPSS (Statistical Package for Social Sciences), Windows Version 16, Chicago, USA ${ }^{[18]}$.

\section{RESULTS}

\section{(I) Results of Serological Investigations}

Measurement of Hormonal Profile of Serum Testosterone Level (ng/ml) in the Studied Groups (Table 1, Histogram1)

A significant reduction in serum Testosterone level was reported in the cisplatin-treated group (group II), in comparison to the control value; representing the least value recorded for serum testosterone level.

Testosterone value in the melatonin-treated group was comparable to control group and was significantly higher in comparison with the chemotherapy treated group. In the combined therapy group, mean testosterone value still represented a significant increase as compared to the cisplatin- treated group, but without significant difference as compared to either the control or melatonin-treated groups.

(II) Results of Biochemical Analysis for measurement for markers of Oxidative Stress : (Table 2, Histograms 2,3)

A significant increase in the mean values of malondialdehyde (MDA) and superoxide was reported in the cisplatin-treated group, in comparison with the control value; representing the highest values recorded for MDA and superoxide levels.

In the combined therapy group, mean MDA and superoxide values represented a significant decrease as compared to the cisplatin- treated group, but still presented significant increase as compared to the control as well as to the melatonin-treated group.

\section{(III) Histological Results}

Hematoxylin
(Figures 1A and 1B)

The histological pictures of the 3 subgroups of the control group were comparable to each others.

Histological examination of the control testicular sections revealed the normal closely packed seminiferous tubules with regular outline and regular thin basement membrane, and the intervening loose vascular interstitial tissue containing Leydig cells. Each tubule was lined with a complex stratified germinal epithelium that contained all types of spermatogenic cells including spermatogonia; both dark type with condensed chromatin \& pale type with dispersed chromatin, primary spermatocytes arranged in one or two layers, spermatids arranged in several layers and spermatozoa. The tubules were also lined by Sertoli cells.

Sections of cisplatin-treated group (group II) revealed loss of the normal architecture of the seminiferous tubules, with marked distortion and irregular outline of most of the tubules and relative widening of the interstitial spaces. Separation and dispersion of the lining spermatogenic cells was more observed in tubules where BM showed discontinuity. Most primary spermatocytes exhibited dark stained nuclei and deep acidophilic cytoplasm. Spermatids were irregularly dispersed. Vacuolations were detected inside the tubules and few sperms were intermingled with shreds of cytoplasmic fragments.

Sections of melatonin-treated group (group III) showed that most of the seminiferous tubules exhibited regular outline, but relatively wide areas of interstitial tissue between the tubules. In some tubules, areas of separation of spermatogenic cells were observed. Tails of maturing spermatozoa were observed projecting into the Lumina of most of the tubules. Most spermatogonia exhibited dark nuclei. Then, primary spermatocytes, in one or two layers, showed fragmented nuclear chromatin. Several layers of spermatids were evident, they often exhibited margination of nuclear chromatin.

Sections of the combined cisplatin and melatonin (Figures 1a.1b.1c.1d) treated group (group IV) showed that most of the seminiferous tubules exhibited regular outline and were separated by relatively wide areas of interstitial tissue containing loose vascular C.T. However, some of the tubules showed areas of spermatogenic cell loss. Tails of maturing spermatozoa were observed projecting into the lumina of most of the tubules. Tubules were lined with the different stages of spermatogenic cells. However, some of the primary spermatocytes exhibited dark pyknotic nuclei and deep acidophilic cytoplasm. Spermatids were arranged in several layers and exhibited central rounded vesicular nuclei.

\section{(IV) Immunohistochemical Results a) Anti-iNOS Stained Testicular Sections (Figure 3)}

Examination of anti-iNOS immunostained testicular sections of the control group revealed negative immunoreactivity of all the cells lining the seminiferous tubules, representing the different stages of spermatogenesis, as well as Sertoli cells. Interstitial Leydig cells exhibited positive immunostaining in the form of moderate brown cytoplasmic reaction. Sections of the cisplatin-treated group revealed that the cytoplasmic processes of some Sertoli cells exhibited moderate to intense immunoreactivity to iNOS. Myoid cells and interstitial cells of Leydig exhibited intense brown immunoreactivity. Endothelial lining of blood vessels also demonstrated intense immunoreactivity. 
Testicular sections of groups III \& IV revealed that cytoplasm of all the spermatogenic cells lining seminiferous tubules demonstrated negative iNOS immunoreactivity (a picture almost comparable with that of the control group). Few processes of Sertoli cells exhibited iNOS immunostaining. Interstitial cells of Leydig exhibited moderate cytoplasmic immunoreactivity (Figure 2).

a) Anti-AR Stained Testicular Sections (Figure 4)

Examination of anti-AR immunostained testicular sections of the control group showed positive nuclear AR immunoreactivity in the myoid cells surrounding the seminiferous tubules, as well as in the Sertoli cells \& their processes and interstitial cells of Leydig. Spermatogenic cells lining the seminiferous tubules expressed negative immunoreactivity. Cisplatin-treated group revealed negative nuclear AR immunoreactivity in Sertoli cells, myoid cells, Leydig cells as well as in the spermatogenic cells.

Melatonin treated group showed anti-AR immunoreactive nuclei of some Sertoli cells. Some Interstitial cells of Leydig exhibited positive nuclear immunoreactivity, while nuclei of myoid cells expressed negative immunoreactivity.Combined group revealed positive nuclear AR immunoreactivity in the myoid cells, as well as in Sertoli cells \& their processes and interstitial cells of Leydig. Spermatogenic cells lining the seminiferous tubules, expressed negative immunoreactivity (Figure 3).

\section{(IV) Morphometric Results}

a- Height of seminiferous epithelium, extending from the basement membrane of the seminiferous tubule towards the lumen (measured in microns): (Histogram 4)

The mean height of seminiferous epithelium was $92.7( \pm 10.2)$ in the control group. This value decreased significantly to reach $30.5( \pm 5.7)$ in cisplatin-treated group, as compared to the control group; representing the least value recorded for the mean height of seminiferous epithelium. The value in the Melatonin treated group was comparable to control value( $83.7 \pm 8.6)$ with no significant
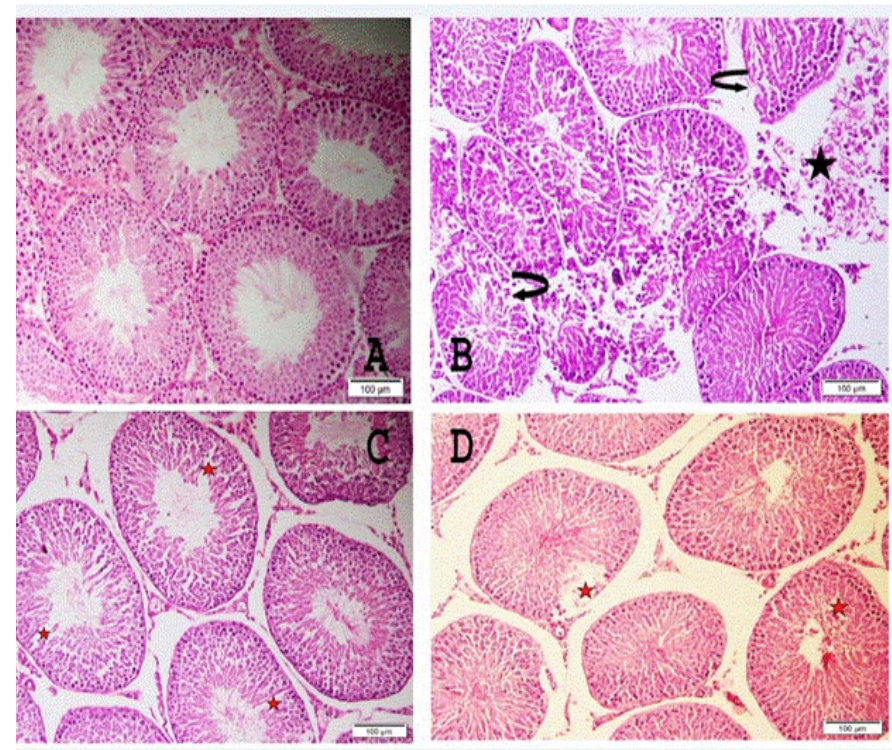

difference. Significant increase $(85.2 \pm 8.6)$ was seen in the combined therapy group when compared to the cisplatintreated group.

However, the value reported for epithelial height in melatonin-treated group, and in the combined therapy group, did not represent a significant difference as compared to the control group, or as compared to each other.

\section{b-Mean optical density of iNOS: (Histogram 5)}

The mean optical density of iNOS $( \pm \mathrm{SD})$, measured in iNOS-immunostained sections, was $0.25( \pm 0.006)$ in the control group. This value showed a statistically significant increase to reach $0.49( \pm 0.012)$ in cisplatin-treated group, as compared to the control group; representing the greatest value recorded.Melatonin treated group showed increase to reach $0.36( \pm 0.009)$, which was significantly higher as compared to control group.

Significant change was demonstrated $(0.32 \pm 0.008)$ in combined therapy group, as compared to the cisplatintreated group. This value was decreased as compared to cisplatin-treated group, but still significantly higher than value of control. Melatonin-treated group and combined therapy groups, showed no significant difference between them.

The mean area \% of AR immunoreactivity was 14.4 $( \pm 3.2)$ in the control group. This value showed a statistically significant decrease to reach $3.6( \pm 0.6)$ in cisplatin-treated group, as compared to the control group; representing the least value recorded.

The value demonstrated in melatonin-treated group (12.1 \pm 2.7$)$, showed no significant difference as compared to the control, while significant increase was seen in the combined therapy group $(9.4 \pm 1.3)$ as compared to the cisplatin-treated group. Value for combined therapy group showed no significant difference from melatonin treated group, but was still significantly lower than control.

Fig. 1: Photomicrographs of sections in the testis: A): Control group showing regular outline of tubules. The tubules display multiple layers of spermatogenic cells, with lumina containing sperms. The tubules are surrounded by loose vascular interstitial tissue. (B): Cisplatin-treated group showing marked distortion and irregular outline of most of the seminiferous tubules, with many areas of discontinuity of the BMs (curved arrows). Fragments of degenerating spermatogenic cells are exfoliated within the intertubular spaces (star). (C):Melatonin-treated group showing regular outline of most of the seminiferous tubules. Intervening spaces are wide and occupied by loose vascular tissue. In some tubules, areas of spermatogenic cell loss are observed (red stars). (D): Combined group showing regular outline of most of the seminiferous tubules. Tubules are separated by relatively wide areas of interstitial tissue containing loose vascular C.T. However, some of the tubules show areas of spermatogenic cell loss (red stars). (H\&E x100) 

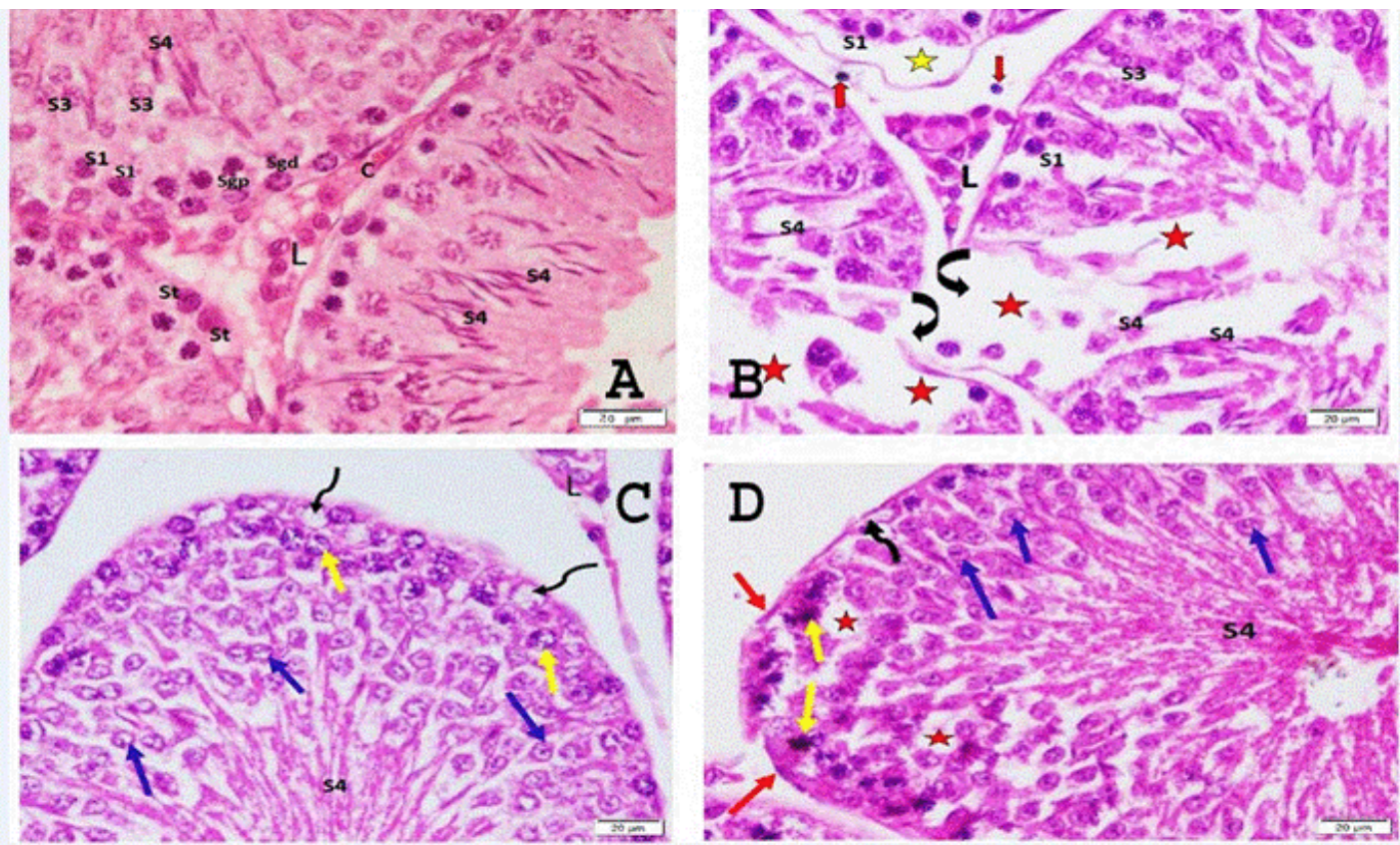

Fig. 2: Photomicrographs of sections in the testis of: (A): Group I showing parts of 3 adjacent seminiferous tubules, lined with spermatogonia [both dark type (Sgd) and pale type (Sgp), primary spermatocytes (S1), spermatids (S3) and spermatozoa (S4), in addition to Sertoli cells (St). Leydig cells (L) are located in the interstitial tissue, near blood capillaries (c). (B): Group II showing parts of adjacent seminiferous tubules. In some areas, separation of the lining spermatogenic cells from the underlying BM is observed (yellow star), while in other areas, discontinuity of the BMs is observed (curved black arrows). The tubules exhibit many vacuolated areas with spermatogenic cell loss (red stars). Most of the primary spermatocytes (S1) exhibit deep-stained nuclei and deep acidophilic cytoplasm. Spermatids (S3) are dispersed. Few sperms (S4) are intermingled with cytoplasmic fragments and residual bodies. Dark pyknotic nuclei are found in the intertubular spaces (short red arrows). Normal appearance of Leydig cells (L). (C): Group III showing part of a seminiferous tubule lined with the different stages of spermatogenic cells. spermatids exhibit margination of nuclear chromatin (blue arrows). Sperms (S4) are encountered within the lumina. (D):Group IV showing flattened myoid cells (red arrows). Some of the primary spermatocytes exhibit dark nuclei and deep acidophilic cytoplasm (yellow arrows). Spermatids exhibit margination of nuclear chromatin (blue arrows). Some areas of the tubules exhibit areas of spermatogenic cell loss (red stars). Sperms are encountered within the lumen (S4). (H \& E x400)

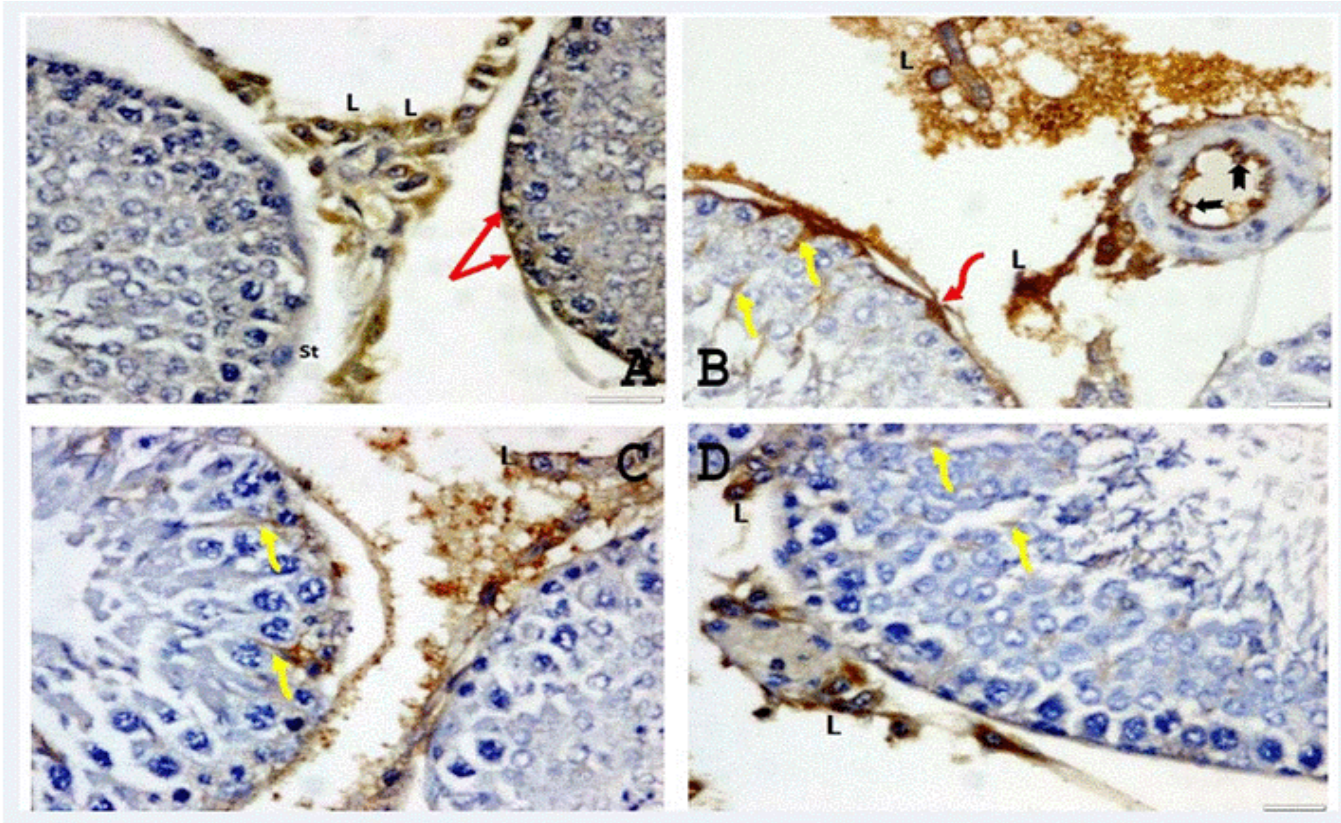

Fig. 3: Photomicrographs of sections in the testis:A): Control group ( I) shows negative iNOS immunoreactivity in the different stages of the spermatogenic epithelium, and in Sertoli cells (St). Leydig cells (L) and some myoid cells (red arrows) exhibit moderate cytoplasmic immunoreactivity. B):Cisplatintreated group (group II) shows that cytoplasmic processes of some Sertoli cells exhibit moderate to intense immunoreactivity (wavy yellow arrows). Myoid cell (wavy red arrow) and interstitial cells of Leydig (L) exhibit intense cytoplasmic immunoreactivity. Endothelial lining of an arteriole in the surrounding interstitial tissue also demonstrates intense immunoreactivity (arrowheads). C): Melatonin-treated group (group III) shows negative immunoreactivity in the cytoplasm of all the spermatogenic cells. Few processes of Sertoli cells exhibit immunostaining (wavy yellow arrows). Interstitial cells of Leydig (L) exhibit moderate cytoplasmic immunoreactivity. D): Combined group (group IV) shows negative cytoplasmic immunoreactivity in all the spermatogenic cells. Few processes of Sertoli cells exhibit mild reaction (wavy yellow arrows). Interstitial cells of Leydig (L) exhibit intense cytoplasmic immunoreactivity. (Anti-iNOS immunostaining $\mathrm{x} 400$ ) 


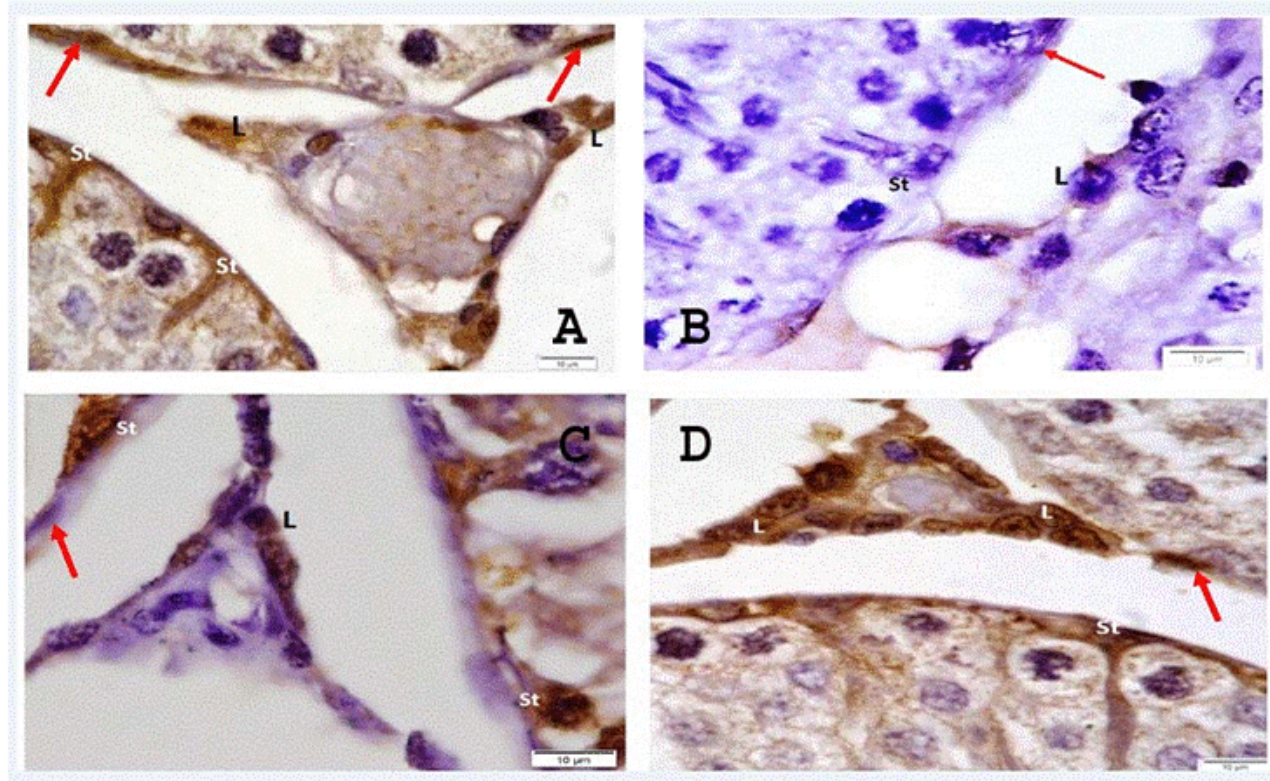

Fig. 4: Photomicrographs of sections in testis: A):Control group shows positive nuclear AR immunoreactivity in the myoid cells surrounding the seminiferous tubules (red arrows), in Sertoli cells \& their processes (St) and interstitial cells of Leydig (L). Spermatogenic cells express negative immunoreactivity.B):Cisplatin-treated group shows negative nuclear immunoreactivity in the myoid cells (red arrow), spermatogenic cells, Sertoli cells (St) as well as Leydig cells (L). C):Melatonin-treated group shows immunoreactive nuclei of some Sertoli cells (St). Some Interstitial cells of Leydig (L) exhibit positive nuclear immunoreactivity, while nuclei of myoid cells (red arrow) express negative immunoreactivity.D): Combined group shows positive nuclear AR immunoreactivity in myoid cell (red arrow), as well as in the Sertoli cell \& its processes (St) and interstitial cells of Leydig (L). Spermatogenic cells express negative immunoreactivity.(Anti AR immunostaining x1000)

Table 1: Measurement of Hormonal Profile of Serum Testosterone Level (ng/ml) in the Studied Groups

\begin{tabular}{lc}
\hline \multicolumn{1}{c}{ Group } & Testosterone $(\mathrm{ng} / \mathrm{ml}) \pm \mathrm{SD}$ \\
\hline Group I (Control) & $3.74 \pm 0.07^{\#}$ \\
Group II (Cisplatin) & $2.01 \pm 0.03^{*}{ }^{\star}$ \\
Group III (Melatonin) & $3.26 \pm 0.05^{\sharp}$ \\
Group IV (Combined) & $3.51 \pm 0.09^{\#}$ \\
\hline
\end{tabular}

$* P<0.05$ as compared to Control $\quad \# P<0.05$ as compared to Cisplatin

${ }_{\Lambda} P<0.05$ as compared to Melatonin $\circ P<0.05$ as compared to Combined

Table 2: Results of Biochemical Analysis for Measurement of Markers of Oxidative Stress

\begin{tabular}{|c|c|c|}
\hline Group & $\begin{array}{c}\mathrm{MDA} \\
(\mathrm{nmol} / \mathrm{mg}) \pm \mathrm{SD}\end{array}$ & $\begin{array}{l}\text { Superoxide } \\
(\mathrm{ng} / \mathrm{ml}) \pm \mathrm{SD}\end{array}$ \\
\hline Group I (Control) & $0.12 \pm 0.02^{\#}$ & $8.1 \pm 0.28^{\#}$ \\
\hline Group II (Cisplatin) & $2.18 \pm 0.05^{* \wedge}$ & $18.1 \pm 3.1^{* \wedge \circ}$ \\
\hline Group III (Melatonin) & $0.19 \pm 0.04^{\# \circ}$ & $9.1 \pm 2.1^{\# \circ}$ \\
\hline Group IV (Combined) & $1.37 \pm 0.07^{*}$ \# & $12.1 \pm 2.1^{* \wedge \#}$ \\
\hline
\end{tabular}

nmol/mg: nanomol per milligram

$\mathrm{ng} / \mathrm{ml}$ : nanogram per milliliter

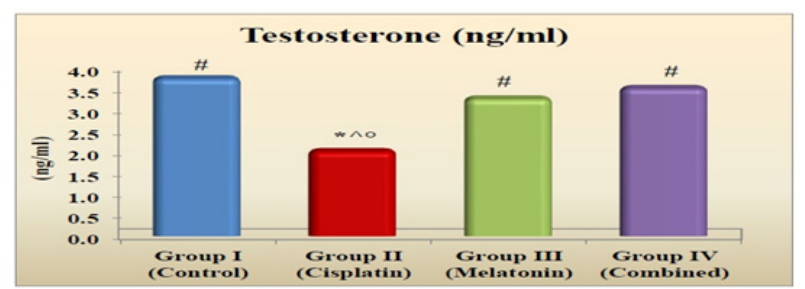

Histogram 1: Comparison between the mean values of Serum Testosterone $( \pm \mathrm{SD})$ in the studied groups

$* P<0.05$ as compared to Control \#P<0.05 as compared to Cisplatin ${ }_{\Lambda} P<0.05$ as compared to Melatonin $\circ P<0.05$ as compared to Combined

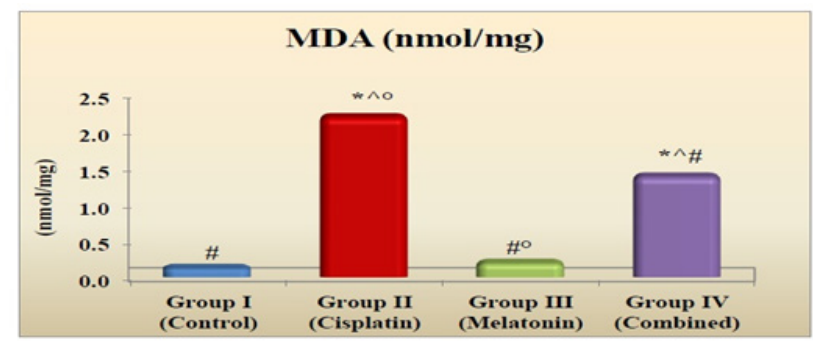

Histogram 2: Comparison between the mean values of MDA in the studied groups

* $P<0.05$ as compared to Control \# $P<0.05$ as compared to Cisplatin ${ }_{\Lambda} P<0.05$ as compared to Melatonin $\circ P<0.05$ as compared to Combined 


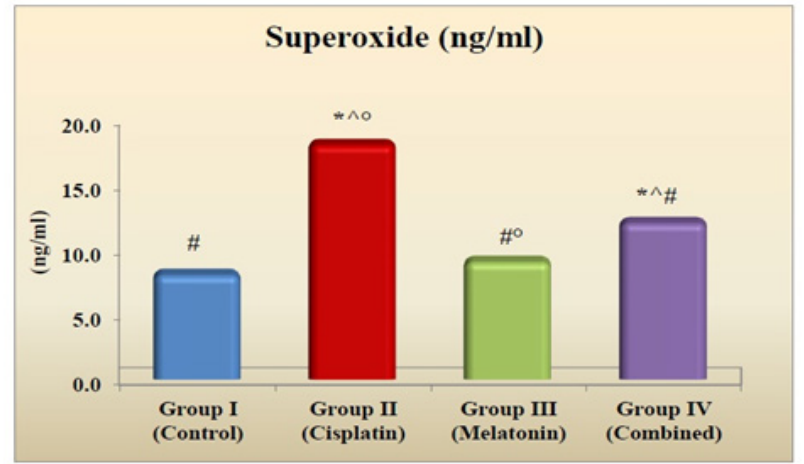

Histogram 3: Comparison between the mean values of Superoxide in the studied groups

* $P<0.05$ as compared to Control \# $P<0.05$ as compared to Cisplatin

${ }_{\Lambda} P<0.05$ as compared to Melatonin $\circ P<0.05$ as compared to Combined

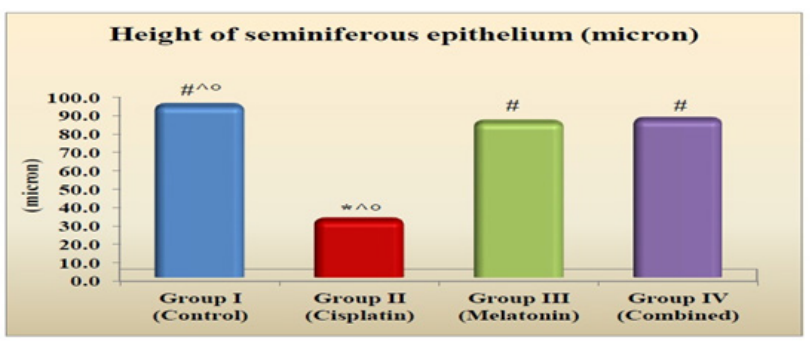

Histogram 4: Comparing the mean values of height of seminiferous epithelium

* $P<0.05$ as compared to Control \# $P<0.05$ as compared to Cisplatin

${ }_{\Lambda} P<0.05$ as compared to Melatonin $\circ P<0.05$ as compared to Combined



Histogram 5: Comparing the mean values of iNOS optical density $* P<0.05$ as compared to Control \# $P<0.05$ as compared to Cisplatin ${ }_{\Lambda} P<0.05$ as compared to Melatonin $\circ P<0.05$ as compared to Combined



Histogram 6: Comparing the mean values of area \% of $\mathrm{AR}$ * $P<0.05$ as compared to Control \# $P<0.05$ as compared to Cisplatin ${ }_{\Lambda} P<0.05$ as compared to Melatonin $\circ P<0.05$ as compared to Combined

\section{DISCUSSION}

The mammalian testicle is vulnerable to toxic environmental and therapeutic agents that decrease spermatogenesis ${ }^{[19]}$.

In the present study, cisplatin was administered I.P. at a single dose of $7 \mathrm{mg} / \mathrm{kg}$. The selected cisplatin dose was based upon results of former studies that could induce testicular toxicity in $\operatorname{rats}^{[5,20]}$.

In the current work, cisplatin administration induced injurious testicular changes. Most of the tubules exhibited disarranged cellular layers and were greatly depleted of germ cells probably due to cell death. The tubules appeared atrophic exhibiting arrested spermatogenesis at the spermatogonia or primary spermatocyte level, and several apoptotic primary spermatocytes were encountered within most of the tubules. Tubules exhibited vacuolated areas, possibly occupied previously by germ cells. Cytoplasmic fragments and residual bodies were present within the tubules.

Loss of spermatogenic cells in the current work was verified by morphometric analysis that showed a statistically significant reduction of the height of seminiferous epithelium in cisplatin-treated animals, as compared to the control. According to ${ }^{[1]}$, the height of the seminiferous epithelium is regarded as are liable feature for assessment of sperm production.

Similar findings had been reported by ${ }^{[21]}$ who described a 'washed out' appearance of the seminiferous tubules, reflecting the degeneration of germinal epithelium and extensive cell loss that occurred after cisplatin therapy. In accordance with this finding ${ }^{[22]}$, mentioned that treatment with cisplatin induced loss of germ cells and seminiferous tubular atrophy.

Reported that cisplatin-based chemotherapy for testicular cancer resulted in temporary azospermia and oligospermia in most men, that was reversible in $50 \%$ and $80 \%$ of the cases at 2 and 5 years respectively ${ }^{[23]}$.

It is well-documented that drug-induced germ cell death is mediated by apoptosis ${ }^{[24]}$. reported at least 3 -fold increase in germ cell apoptosis in cisplatin-treated rats.Cisplatininduced germ cell apoptosis resulted in spermatogenic arrest in the current study. The chemical basis of testicular injury might be attributed to the ability of this efficient platinum-derived alkylating agent to act in specific phases of the cellular cycle against the proliferating germ cells. Its effect is exerted mainly during the " $\mathrm{S}$ " phase, binding to and causing crosslinking of DNA, which ultimately triggers apoptosis ${ }^{[2]}$.

Autocrine and paracrine interaction between different testicular cell types affect the spermatogenesis and the disruption of AR in an experimental animal gives a clue about the important role of AR in each type of testicular cells during spermatogenesis. Reduction of AR in Sertoli 
cells prevent the function of the latter to provide support and nutrition to the germ cells, with subsequent stoppage of spermatogenesis arrest at the primary spermatocyte stage before proceeding into the first meiotic division ${ }^{[17]}$.

Peritubular myoid cells are from the main receptors that respond to androgen to mediate the process of spermatogenesis under androgenic control. Myoid cells contain ARs and provide a site for androgen signaling ${ }^{[25]}$.

In the present work, exfoliation of spermatogenic cells happened probably secondary to decrease in the number of germ cells in addition to the retraction of the cytoplasmic processes of Sertoli cells, which were extending between the different layers of spermatogenic cells and supporting them, that finally led to loose arrangement and easily separation of the cells. The large vacuoles and intercellular spaces detected in the tubules of the present study were previously reported ${ }^{[26]}$. Mentioned that degenerating spermatogenic cells in testes exposed to cisplatin underwent complete lysis after which only cytoplasmic remnants remained detectable as 'ghost cells'.

It has been previously reported that free radicals mediate reactions that are responsible for a wide range of cisplatininduced side effects. Reactive oxygen species (ROS) have been recognized as being involved in the pathogenesis of cisplatin-induced testicular toxicity[2].

Direct measurement of oxidative stress in humans is difficult because the active oxygen species and free radicals are extremely short-lived. Instead, lipid peroxidation products are measured. The accumulation of lipid peroxidation products has been extensively studied and implicated in many toxic tissue injuries and in pathological processes. In particular, the measurement of free MDA in biological samples from subjects affected by several diseases has been widely utilized, indirectly implicating MDA in the pathogenesis of these diseases ${ }^{[28]}$.

Biochemical parameters assessed in this work revealed a statistically significant elevation in MDA and superoxide in the testicular tissue of cisplatin-treated animals, as compared to the control rats. The balance between oxidant and antioxidant system seems to be disturbed by cisplatin treatment. These findings go in accordance with other researchers who reported testicular production of free radicals after exposure to cisplatin. Cisplatin therapy induced lipid peroxidation and reduced the activity of enzymes that protect against oxidative damage in the testes $^{[29]}$.

Testicular tissues are very sensitive to ROS effects. Additionally, sperm membranes consist of dense unsaturated fatty acids that make spermatozoa sensitive to oxygen-induced damage mediated by lipid peroxidation and free radicals ${ }^{[30]}$ Elevated levels of ROS may damage DNA, lipids, proteins and enzymes of the tissue. Cisplatin has been shown to induce testicular toxicity due to membrane rigidification and lipid peroxidation. MDA level ${ }^{[24]}$
Under conditions of oxidative stress, MDA adducts are generated. These adducts are also referred to as advanced lipid peroxidation end-products (ALEs). MDA adducts are biologically important because they can participate in secondary deleterious reactions (e.g., cross linking) by promoting intramolecular or intermolecular protein/DNA crosslinking that may induce profound alteration in the biochemical properties of biomolecules and accumulate during testicular toxicity ${ }^{[31]}$.

Superoxide dismutase generally dismutases the superoxide anion radical into hydrogen peroxide which is degraded by catalase into water and oxygen. Reduction in the activity of catalase may reflect inability of testicular microsomes to eliminate hydrogen peroxide produced after cisplatin treatment. This may lead to disruption of functional integrity of cell organelles ${ }^{[32]}$.

In the present study, melatonin was given orally at a dose of $8 \mathrm{mg} / \mathrm{kg} /$ day at 5:00 pm. This dose was selected on the basis of previous results in which the anti-oxidant action of this agent was apparent ${ }^{[6]}$. Melatonin was given at a fixed time daily at $5 \mathrm{pm}$ throughout the duration of the experiment to preserve the circadian rhythm of melatonin as it is naturally secreted in the dark and this would promote better melatonin effect ${ }^{[33]}$. Reported that melatonin fastened neuronal healing and induced better nerve regeneration when the animals received melatonin during the dark period at 5:00 pm daily.

In the current study, when melatonin was administered alone, most of the seminiferous tubules were lined by several layers of spermatogenic epithelium, although many cells did not exhibit normal histological appearance. Spermatids often exhibited margination of nuclear chromatin. Some apoptotic cells were observed within some of the tubules. Sertoli cells' processes ramified in between the developing spermatogenic cells, which might explain the presence of several layers of spermatogenic epithelium; being supported by the ramifying processes. In some tubules, lysis of nuclear chromatin of Sertoli was evident. Leydig cells in the interstitial spaces exhibited apparently normal histological appearance.

Margination of nuclear chromatin encountered in spermatids might represent a stage of cellular degeneration ${ }^{[34]}$ reported that margination of chromatin is a relevant indicator of the cellular state in certain pathological processes.

On the other hand, testicular sections of the combined group revealed histological picture comparable to the control, in the form of regular outline of most of the seminiferous tubules, which were lined with the different stages of spermatogenic cells and tails of maturing spermatozoa were observed projecting into the lumina of most of the tubules, suggesting improved spermatogenesis, with increased number of spermatogenic cells and epithelial thickness; this certainly would be manifested clinically as improved fertility. However, some of the tubules showed areas of spermatogenic cell loss and some 
of the primary spermatocytes exhibited dark pyknotic nuclei and deeply acidophilic cytoplasm. Most of Sertoli cells appeared normal, while few were distorted and their cytoplasmic processes were disorganized. Leydig cells exhibited normal histological appearance. According to morphometric analysis, a statistically significant increase in the height of spermatogenic epithelium was reported in both the group which received melatonin only, as well as in the combined group, as compared to the cisplatin-treated group.

Biochemical markers of oxidative stress and lipid peroxidation products; MDA and superoxide, in both groups, represented a statistically significant decrease as compared to the chemotherapy group, indicating activation of antioxidant defense system induced by melatonin and decline of oxidative stress. Consistently ${ }^{[35]}$, mentioned that melatonin is a potent antioxidant agent in preventing testicular post-ischemic reperfusion injury.

To assess the influence of testosterone level on spermatogenesis in these groups, serological investigations showed that testosterone value presented a significant increase in both groups, as compared to the cisplatintreated group. However, testosterone level was still less than the control value, but without statistically significant difference. This would explain better progress of spermatogenesis in the mentioned groups. In agreement with our findings ${ }^{[36]}$, found that exogenous melatonin increased the levels of serum free testosterone, LH and $\mathrm{FSH}$, as well as expression of their encoding genes in male rats.

Meanwhile, testicular sections stained with antiAR antibody in the melatonin-treated group revealed immunoreactive nuclei of some of Sertoli cells and some interstitial cells of Leydig, while nuclei of myoid cells expressed negative immunoreactivity. Testicular sections of the combined group revealed positive nuclear AR immunoreactivity in the myoid cells, as well as in the Sertoli cells \& their processes and interstitial cells of Leydig. Morphometric analysis revealed a statistically significant increase in the mean area percent of AR in both groups, as compared to the control value. This finding would explain improved spermatogenesis with melatonin administration prior to and concomitant with cisplatin, through upregulation of AR in Sertoli cells, myoid cells and Leydig cells.

These data suggest a possible protective effect of melatonin on testicular architecture, when administered to patients prior to and during the period of cisplatin therapy. Melatonin, by exerting antioxidant properties, could combat the injurious effect of cisplatin on testicular morphology. However, melatonin administered alone seems to induce some injurious effects on the testes.

\section{CONFLICTS OF INTEREST}

There are no conflicts of interest.

\section{REFERENCES}

1. Soni KK, Kim HK, Choi BR, Karna KK, You JH, Cha JS, Shin YS, Lee SW, Kim Cy and Park JK (2016): Dose-dependent effects of cisplatin on the severity of testicular injury in Sprague Dawley rats: reactive oxygen species and endoplasmic reticulum stress.Drug Des DevelTher.; 10: 3959-3968.

2. Sajjad H (2012): Toxicity effect of cisplatin treatment on rat testis tissue. Annals of Biological Research; 3 (5):2297-2303.

3. Turk G, Atessahin A, Sçnmez M, Ceribasi AO and Yuce A (2008): Improvement of cisplatin-induced injuries to sperm quality, the oxidant-antioxidant system, and the histologic structure of the rat testis by ellagic acid. FertilSteril.; 89:1474-1481.

4. Iibey YO, Ozbek E, Simsek A, Otunctemur A, Cekmen M and Somay A (2009): Potential chemoprotective effect of melatonin in cyclophosphamide and cisplatin-induced testicular damage in rats. FertilSteril.; 92:1124-1132.

5. Sahu BD, Rentam KK, Putcha UK, Kuncha M, Vegi GM and Sistla R (2011):Carnosic acid attenuates renal injury in an experimental model of rat cisplatin-induced nephrotoxicity. Food ChemToxicol.; 49(12):3090-3097.

6. Kilic U, Kilic E, Tuzcu Z, Tuzcu M, Ozercan I, Yilmaz O, Sahin F and Sahin K (2013): Melatonin suppresses cisplatin-induced nephrotoxicity via activation of Nrf-2/HO-1 pathway. Nutrition \& Metabolism; 10:7-15.

7. KunduJK et al. (2006): Resveratrol inhibits phorbol ester-induced expression of COX-2 and activation of NF-kappaB in mouse skin by blocking IkappaBkinase activity. Carcinogenesis; 27: $1465-1474$.

8. Pourghasem M, Nasiri E and Shafi H (2014): Early renal histological changes in Alloxan-induced diabetic rats. Int J Mol Cell Med.; 3: 11-15.

9. Lowery OH.,Rosebrough NJ., and Farr AL (1951): Protein measurement with Folin-phenol reagent J.Biol. Chem: 193: 571-575.

10. Del Rio D, Stewart AJ and Pellegrini N (2005):A review of recent studies on malondialdehyde as toxic molecule and biological marker of oxidative stress. NutrMetabCardiovasc Dis.; 15 (4): 316-328

11. Okhawa H., Ohishi N., and Yagi K. (1997): Assay for lipid peroxidesa in animal tissues by thiobarbituric acid rection. Anal. Biochem.; 95: 351-358. 
12. Muller F L, Lustgarten M S, Jang Y, Richardson A. and Van Remmen H (2007): Trends in oxidative aging theories. Free Radic. Biol. Med.; 43, 477-503.

13. Min JK, Lee CH and Jang SE (2015): Liquiritigenin ameliorates TNBS-induced colitis in mice. Journal of Gastroenterology and Hepatology; $30(5): 858-865$.

14. Kiernan JA (2001):Histological and histochemical methods: theory and practice. 3rd ed., Arnold publisher, London, New York \& New Delhi: 111-162.

15. Bancroft JD and Gamble M (2007): Connective tissue stains. In: Theory and practice of histological techniques, sixth edition. Elsevier health Sciences, Churchill Livingstone, Edinburgh, London, Oxford,New York, Philadelphia, St. Louis, Sydney and Toronto: 150.

16. Asgharzade S, Rafieian-kopaei M, Mirzaeian A, Reiisi S and LoghmanSalimzadeh L (2015): Aloe vera toxic effects: expression of inducible nitric oxide synthase (iNOS) in testis of Wistar rat. Iran J Basic Med Sci.:18(10): 967-973

17. Wang RS, Yeh $\mathrm{S}$, Tzeng $\mathrm{CR}$ and Chang $\mathrm{C}$ (2009):Androgen receptor roles in spermatogenesis and fertility: lessons from testicular cell-specific androgen receptor knockout mice. Endocr Rev.; 30(2):119-132.

18. Emsley R, Dunn G and White IR (2010): Mediation and moderation of treatment effects in randomized controlled trials of complex intervention. State. Methods Med. Res.; 19: pp. 237-270.

19. Cortes D, Thorup J and Visfeldt J (2000): Hormonal treatment may harm the germ cells in 1 to 3 year-old boys with cryptorchidism. J Urol.; 163:1290- 1292.

20. Atessahin A, Karahan I, Türk G, Gür S, Yilmaz $S$ and Ceribaşi AO (2006) a: Protective role of lycopene on cisplatin-induced changes in sperm characteristics, testicular damage and oxidative stress in rats. Reprod.Toxicol.:21(1):42-47.

21. Seaman F, Sawhney P, Giammona CJ and Richburg JH (2003):Cisplatin-induced pulse of germ cell apoptosis precedes long-term elevated apoptotic rates in $\mathrm{C} 57 / \mathrm{BL} / 6$ mouse testis. Apoptosis: 8:101- 108 .

22. Delbes G, Chan D and Pakarinen P (2009): Impact of thechemotherapy cocktail used to treat testicular cancer on the gene expression profile of germ cells from male Brown-Norway rats. BiolReprod.; $80: 320-327$.

23. Howell SJ and Shalet SM (2005): Spermatogenesis after cancer treatment: damage and recovery.J Natl Cancer InstMonogr.; 34:12-27.
24. Martins NM, Santos NA, Curti C, Bianchi ML and Santos AC(2008):Cisplatin induces mitochondrial oxidative stress with resultant energetic metabolism impairment, membrane rigidification and apoptosis in rat liver. J ApplToxicol.; 28(3):337-344.

25. Romano F, Tripiciano A, Muciaccia B, De Cesaris P, Ziparo E, Palombi F and Filippini A (2005): The contractile phenotype of peritubular smooth muscle cells is locally controlled: possible implications in male fertility. Contraception: 72: 204- 297.

26. Shaha C, Tripathi R and Mishra D P (2010): Male germ cell apoptosis: regulation and biology. Philos Trans R SocLond B Biol Sci.; 365(1546): 1501- 1515 .

27. Atessahin A, Sahna E and Turk G (2006) b:Chemoprotective effect ofmelatonin against cisplatin-induced testicular toxicity in rats. J Pineal Res.; 41:21-27.

28. Garcia SC, Grotto D and Bulcao RP (2013): Evaluation of lipiddamage related to pathological and physiological conditions. Drug and Chemical Toxicology; 6 (3):306-312.

29. Aitken RJ, Jones KT and Robertson SA (2012): Reactive oxygen speciesand sperm function in sickness and in health. J Androl.; 33:1096-1106.

30. Sheweita SA, Tilmisany AM and Al-Sawaf H. (2005): Mechanisms ofmale infertility: role of antioxidants. Curr Drug Metab.; 6: 495-501.

31. Pizzimenti S, E. Ciamporcero E and DagaM (2013):Interactionof aldehydes derived from lipid peroxidation and membrane proteins. Frontiers in Physiology(4), article 242.

32. MadhuP, Reddy PKand Sreenivasula Reddy PS (2015): Role of melatonin in mitigating chemotherapy-induced testiculardysfunction in Wistar rats. Drug ChemToxicol, Early Online: $1-10$.

33. Rateb EE, Amin SN, El-Tablawy N, Ahmed Rashed LAand El-Attar S (2017): Effect of melatonin supplemented at the light or dark period on recovery of sciatic nerve injury in rats. EXCLI Journal;16:138-150.

34. Young IT, Verbeek PW and Mayall BH (1986): Characterization of Chromatin Distribution in Cell Nuclei. Cytometry; 7:467- 474.

35. Koksal M, Oğuz E and Baba F (2012): Effects of melatonin on testis histology, oxidative stress and spermatogenesis after experimental testis ischemia-reperfusion in rats.Eur Rev Med Pharmacol Sci.;16:582- 588.

36. Khalil W KB and Abdu F (2015): Protective effect of melatonin against zonisamide-induced reproductive disorders in male rats. Arch Med Sci.; 11(3): 660- 669 . 
الملخص العربى

المحتمل للميالتونين علي سمية الخصية المستحث بالسيسبالتين في الجرذان البيضاء

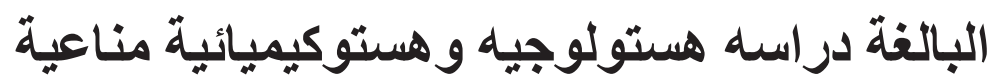

\section{سهير أسعد فيليب، نهي محمد عفيفي أمين، مير الفاروق يوسف يعقوب، خالد رجب عبد الحكيم

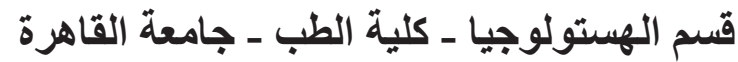

صمدت الدراسة الحالية لتقييم التأثير الوقائي المحتمل لعقار الميالتونين في نموذج الجرذ المصاب بسمية الخصية المستحث بالسيسبالتين. المقدمه: وقد أجريت هذه الدر اسة على خمسةٍ وأربعين من ذكور الجرذان البيضاء البالغة من العمر، و التي يتراوح

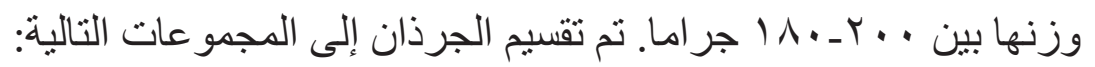
ـ ـ المجموعة الاولى (المجموعة الضابطة): تضمنت خمسة عشرجرذاً التي تلقت 9 , • ٪ كلوريد الصوديوم [المذيب للسيسبالتين] و / أو الماء المقطر [المذيب للميالتونين] بنفس طرق إعطاء العقار اتللمجموعات التجريبية المقابلة. r ـ المجمو عة الثانية (المجموعة المعالجة بالسيسبالتين): تضمنت عشرة جرذان التي تم حقنها داخل الغشاء البريتوني بجرةٍٍ واحدة من سيسبالتين V ملليجر ام / كيلوجر ام. تم التضحية بالجرذان بعد عشرة أيام من حقن السيسبالتين. بـ المجمو عة الثالثة (المجمو عة المعالجة بالميالتونين): تضمنت عشرة جرذان التي تلقت الميالتونين يومياً عن طريق الفم بجر عة ^ ملليجر ام / كيلوجر ام/ يوم في الساعة . ..0 مساء لمدة عشرة أيام. عـ المجموعة الر ابعة (المجموعة المعالجة مسبقاً بالميالتونين / ثم السيسبالتين مع الميالتونين): تضمنت عشرة جرذان التي بدأت العلاج بالميالتونين يومياً عن طريق الفم قبل خمسة أبام من حقنها بجرعة واحدة من السيسبالتين داخل الغشاء البريتوني، تالها استمر ار العالج بالميالتونين لمدة عشرة أيام اخري. تم التضحية بالفئر ان بعد عشرة أيام من حقن السيسبالتين. نتائج الدراسة : اثبتت الدراسة التأثير الوقائي لعقار الميالتونين ضد سمية الخصية حين اعطاؤه قبل عقار السيسبالتين ثم معه، بينما سبب الميالتونين بعض الضرر علي الخصية عند اعطاؤه. 